\title{
Traumatic Pulmonary Artery Dissection: A Case Report
}

\author{
Travmatik Pulmoner Arter Diseksiyonu: Olgu Sunumu
}

Saniye Göknil Çalık', Mustafa Çalık², Atilla Can², Hıdır Esme²

\begin{abstract}
Pulmonary artery dissection (PAD) is a rare condition that is usually observed in cases with underlying pulmonary arterial hypertension. However, there are several factors related to the etiology of the disease. Presently described is a case of PAD that developed secondary to trauma. A 42-year-old man presented with left chest pain after a fall from a height. His past medical history and physical examination were unremarkable except for pain in the left hemithorax. He had no other complaints. All routine laboratory blood tests were normal. A radiological examination revealed left hilar enlargement and lower lobe PAD. Medical treatment was prescribed. The general condition of the patient was good and as there were no other symptoms, a conservative approach was pursued. In this case, there was pulmonary hypertension, and it is thought that the trauma led to PAD. This is extremely rare in the literature.
\end{abstract}

Key words: Trauma, pulmonary artery, dissection.

\section{Özet}

Pulmoner arter disseksiyonu nadir bir durumdur, ancak genellikle pulmoner arteriyel hipertansiyonu olan vakalarda görülür. Bununla birlikte, hastalığın etiyolojisinde farklı faktörlerin bir bağlantısı vardır. Biz travmaya bağlı gelişen pulmoner arter diseksiyonlu olguyu sunduk. Kırk iki yaşındaki erkek, yüksek düşme ve sol göğüs ağrısı nedeni ile hastanemiz acil servisine başvurdu. Anamnez ve fizik muayenesinde sol hemitoraks üzerinde ağrı dışında bir özellik yoktu. Başka hiçbir şikâyeti yoktu. Tüm rutin laboratuvar kan testleri normaldi. Radyolojik incelemesinde sol hiler genişleme ve alt lob pulmoner arter disseksiyonu tespit edildi. Tıbbi tedavi verildi. Genel durumu iyi ve semptomsuz olarak konservatif tedaviyle taburcu edildi. Bizim olgumuzda, var olan pulmoner hipertansiyona eklenen travmanın pulmoner arter diseksiyonuna neden olduğunu düşünüyoruz. Bu durum literatürde son derece nadirdir.

Anahtar Sözcükler: Travma, pulmoner arter, diseksiyon.
Pulmonary artery dissection (PAD) was first reported by Helmbrecht in 1842 (1). The condition generally presents as a cardiogenic shock or sudden death because the dissection proceeds swiftly; it is therefore usually diagnosed in post-mortem examinations (2). Recent improvements in imaging techniques have resulted in earlier diagnoses (1). In this case, PAD developed secondary to trauma.

'Emergency and First Aid Program, Vocational School of Health

Services KTO Karatay University, Konya, Turkey

${ }^{2}$ Department of Thoracic Surgery, Health Sciences University, Konya Training and Research Hospital, Konya, Turkey

'KTO Karatay Üniversitesi Sağlık Hizmetleri Meslek Yüksek Okulu, Illk ve Acil Yardım Programı, Konya

${ }^{2}$ Sağlık Bilimleri Üniversitesi Konya Eğitim ve Araştırma Hastanesi, Göğüs Cerrahisi Kliniği, Konya

Submitted (Başvuru tarihi): 28.08.2017 Accepted (Kabul tarihi): 13.10.2017

Correspondence (iletişim): Mustafa Çalık, Department of Thoracic Surgery, Health Sciences University, Konya Training and Research Hospital, Konya, Turkey

e-mail:drmcalik@hotmail.com 


\section{CASE}

A 42-year-old man presented with left chest pain that developed following a fall from a height. The pain had gradually worsened and was exacerbated by movement of the left hemithorax. His medical history did not indicate any lung disease or pulmonary hypertension. A physical examination was unremarkable except for pain in the left hemithorax. Respiratory sounds were slightly decreased in the left hemithorax. His routine laboratory blood test results, including complete blood count, erythrocyte sedimentation rate, tumor markers, lactate dehydrogenase, serum electrolytes, and kidney and liver function tests were all within the normal ranges. On an X-ray (Figure 1), left hilar enlargement was detected. A contrast-enhanced thoracic CT (Figure 2) image revealed that the enlarged hilar structure was the pulmonary artery. Left lower lobe pulmonary artery (PA) dissection confirmed it. Seconddegree tricuspid insufficiency was detected in an echocardiographic evaluation. PA pressure was measured at $100 \mathrm{mmHg}$. Examination was negative for Behcet's disease and the patient had no history of syphilis. The general condition of the patient was good and had no other symptoms, so a conservative approach was pursued. Medical treatment was prescribed, he was discharged without any complaints, and followed up for 6 months without any sign of problem. Written informed consent was obtained from the patient who participated in this study.

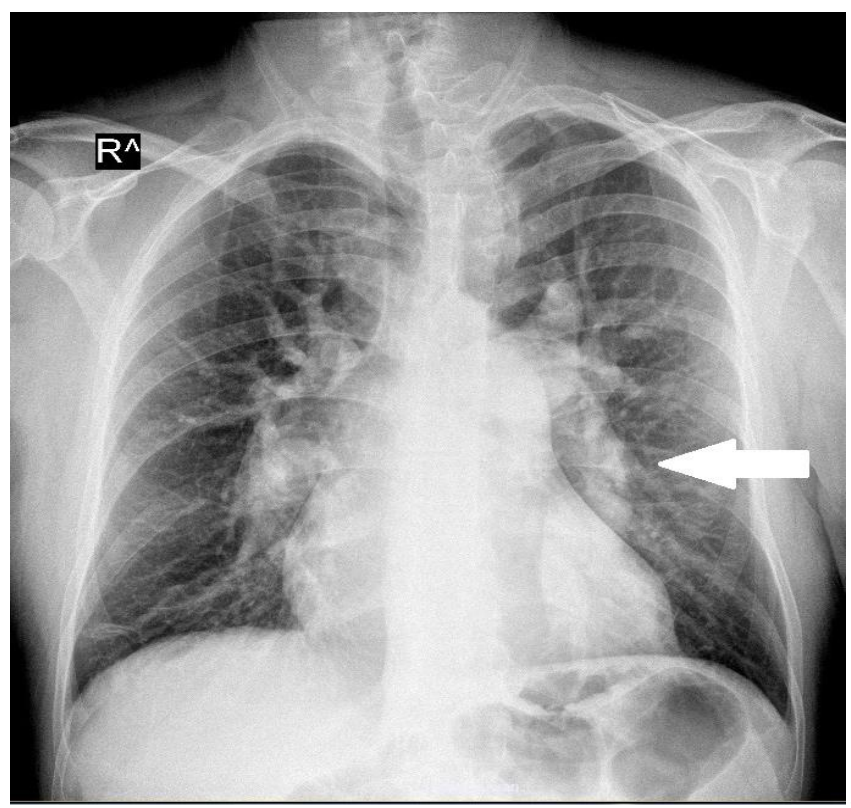

Figure 1: Distention in the bilateral hilar region causing a large area of opacity and tubular opacity of the enlarged lobar branch of the pulmonary artery branch in the superposing sight with the left lower thoracic heart can be seen (white arrow)

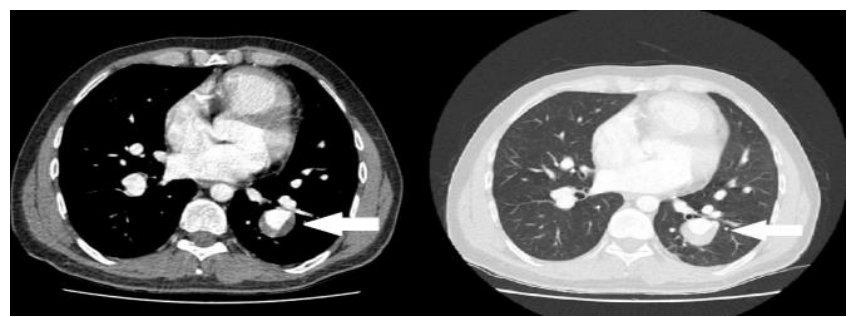

Figure 2: Thorax computed tomography cut-off: A view of a true lumenlike, crescent-shaped dissection that looks like a false lumen thrombosis in the lobar and segmental pulmonary arteries leading to the left lower lobe of the lung (white arrows)

\section{DISCUSSION}

Pulmonary artery dissection (PAD) is an extremely rare and potentially fatal disease usually diagnosed in a postmortem examination. PAD is typically a complication of chronic pulmonary hypertension causing a PA aneurysm. Congenital heart anomalies causing prolonged high pulmonary artery flow rates and pulmonary hypertension have been associated with PAD.

Generally, there is a patent ductus arteriosus in cases of congenital cardiac pathologies. PAD may also occur in patients without pulmonary hypertension. (1) Other rare causes include chronic inflammation of the PA, right heart endocarditis, amyloidosis, trauma, and severe atherosclerosis (3). Despite the frequent association between chronic obstructive pulmonary disease and pulmonary hypertension, PAD has rarely been reported in this group of patients (1). The presence of multiple arterial aneurysms reported on both the systemic and pulmonary vascular tree has been associated with congenital musculoskeletal abnormalities (4). We do not know the exact etiology of PAD in our patient.

The main PA is involved in $80 \%$ of PAD cases. However, isolated cases with right or left pulmonary artery involvement have also been seen. Localized small dissections are unusual. Since rupture causes cardiogenic shock and sudden death, diagnosis is rare in the living, and PAD is frequently only detected in an autopsy (5). Khattar et al. (6) stated that only 8 (12.6\%) of 63 cases were diagnosed with PAD while alive, and that 34 (53.9\%) of the cases had congenital heart disease. PAD usually occurs in patients with medial degeneration and PA dilatation due to a chronic increase in PA pressure (7). PAD is observed, most often, at the site of maximal dilatation of the PA. The false lumen tends to rupture rather than propagate distally or develop a re-entry site (8). The evolution is usually rupture of the vessel with blood flowing into the mediastinum, pericardium, or lung, because there is no exit from the false lumen (9). With increasing survival for patients with PA hypertension, complications such as PAD 
may become more common (10). In patients with pulmonary hypertension, new chest pain, acute chest pain, or cardiogenic shock should raise the suspicion of PAD, which can result in sudden death (9).

\section{CONCLUSION}

In our case, there was pulmonary hypertension and we believe that trauma caused the pulmonary artery dissection. This condition is extremely rare in the literature.

\section{CONFLICTS OF INTEREST}

None declared.

\section{AUTHOR CONTRIBUTIONS}

Concept - S.G.Ç., M.Ç., A.C., H.E.; Planning and Design - S.G.Ç., M.Ç., A.C., H.E.; Supervision - S.G.Ç., M.Ç., A.C., H.E.; Funding - S.G.Ç., M.Ç., A.C., H.E.; Materials - S.G.Ç., M.Ç., A.C., H.E.; Data Collection and/or Processing - S.G.Ç., M.Ç.; Analysis and/or Interpretation - S.G.Ç., M.Ç.; Literature Review - S.G.Ç., M.Ç.; Writing - S.G.Ç., M.Ç., A.C.; Critical Review S.G.Ç., M.Ç., A.C., H.E.

\section{YAZAR KATKILARI}

Fikir - S.G.Ç., M.Ç., A.C., H.E.; Tasarım ve Dizayn S.G.Ç., M.Ç., A.C., H.E.; Denetleme - S.G.Ç., M.Ç., A.C., H.E.; Kaynaklar - S.G.Ç., M.Ç., A.C., H.E.; Malzemeler - S.G.Ç., M.Ç., A.C., H.E.; Veri Toplama ve/veya İşleme - S.G.Ç., M.Ç.; Analiz ve/veya Yorum S.G.Ç., M.Ç.; Literatür Taraması - S.G.Ç., M.Ç.; Yazıyı Yazan - S.G.Ç., M.Ç., A.C.; Eleştirel İnceleme - S.G.Ç., M.Ç., A.C., H.E.

\section{REFERENCES}

1. Perrotta S, Lentini S. Pulmonary artery dissection. J Card Surg 2015; 30:442-7. [CrossRef]
2. Turkvatan A, Altinsoy D, Akgul A, Olçer T, Cumhur T. Pulmonary artery dissection diagnosed by multidetector computed tomographic angiography: case report. Turkiye Klinikleri Cardiovascular Sciences 2009; 21:292-6.

3. Bhatia V, Sharma S, Panda P, Sood RG. Role of multidetector computed tomography (MDCT) in diagnosis of pulmonary artery dissection: a aare but fatal entity. Ann Acad Med Singapore 2014; 43:64-5.

4. Lentini S, Zito C, David A, Gaeta R. Congenital musculoskeletal abnormalities associated with aortic, pulmonary and iliac aneurysms. Cardiol J 2010; 17:412-4.

5. Yaman M, Arslan U, Ateş AH, Aksakal A. Pulmonary arterial dissection in a post-partum patient with patent ductus arteriosus: Case report and review of the literature. World J Cardiol 2015; 7:101-3. [CrossRef]

6. Khattar RS, Fox DJ, Alty JE, Arora A. Pulmonary artery dissection: an emerging cardiovascular complication in surviving patients with chronic pulmonary hypertension. Heart 2005; 91:142-5. [CrossRef]

7. Inayama $Y$, Nakatani $Y$, Kitamura H. Pulmonary artery dissection in patients without underlying pulmonary hypertension. Histopathology 2001 ; 38:435-42. [CrossRef]

8. Senbaklavaci Ö, Kaneko Y, Bartunek A, Brunner C, Kurkciyan $E$, Wunderbaldinger $P$, et al. Rupture and dissection in pulmonary artery aneurysms: incidence, cause, and treatment-review and case report. J Thorac Cardiovasc Surg 2001; 121:1006-8. [CrossRef]

9. Corrêa Rde A, Silva LC, Rezende CJ, Bernardes RC, Prata TA, Silva HL. Pulmonary hypertension and pulmonary artery dissection. J Bras Pneumol 2013; 39:238-41.

10. Cook R, Duarte AG, Boor P, Daniel C. Chronic pulmonary artery dissection associated with pulmonary arterial hypertension. Pulm Circ 2013; 3:692-5. [CrossRef] 